\title{
Factors Affecting Ghanaian Consumers' Purchasing Decision of Bottled Water
}

\author{
Fidelis Quansah ${ }^{1}$, Abednego Okoe ${ }^{1} \&$ Benjamin Angenu ${ }^{1}$ \\ ${ }^{1}$ Faculty of Management, University of Professional Studies Accra, Ghana \\ Correspondence: Fidelis Quansah, Faculty of Management, University of Professional Studies Accra, P. O. Box \\ LG 149, Legon, Accra, Madina, Ghana. Tel: 233-20-811-9637. E-mail:okoe67@yahoo.com
}

Received: June 23, 2015 Accepted: July 10, 2015 Online Published: September 29, 2015

doi:10.5539/ijms.v7n5p76 URL: http://dx.doi.org/10.5539/ijms.v7n5p76

\begin{abstract}
The objective of the study was to examine the factors influencing consumers' choice of bottled drinking water. The survey research design was employed. Questionnaire was used as the data collections instrument. The items measuring the constructs were adapted from the extant literature. A sample size of two hundred and forty (240) bottled water consumers answered the questionnaire. Data was analysed using ANOVA and correlation test. The Statistical Package for Social Sciences Software was used to analyse the data. The results show that there is a relationship between age categories, income groups, educational levels and bottled water buying behaviour in the Ghanaian market. Again, the study found a relationship between perception and beliefs of bottled water usage. Furthermore, quality, brand price, availability and package were found to influence consumers' choice of bottled water. Recommendations have been provided at the end of the study. Studies of this nature are very rare in Ghana making this study novel.
\end{abstract}

Keywords: bottled water, consumer behaviour, purchasing decision, consumer, Ghana

\section{Introduction}

As it is with any other consumer product, bottled water demands thorough research with respect to consumer buying behaviour to serve as a guide to which present and future marketing activities should follow. This is more so, given the circumstances that the bottled water market is considered as one of the fastest growing markets in the beverage category. More recently, in 2008 the global bottled water consumption grew $4.5 \%$ to 218 billion liters, according to a report from drinks consultancy Zenith International (Palmer, 2009). If this increasing trend should continue, the global water market was forecast to have a value of $\$ 86,421.2$ million in 2011 , an increase of nearly $42 \%$ since 2006 (Wikipedia, 2010). The value of the global bottled water market increase obviously parallels the consumption. In 2012 the global bottled water market is forecast to have a value of $\$ 94.2$ billion, an increase of $41 \%$ since 2007 . In spite of the decline in growth the previous year in bottled water value, consultants expect every region of the market to post growth in 2010 (Drake, 2010).

In recent times, bottled water consumption has risen exponentially, globally and locally. But the reasons for bottled water consumption seem to vary; both by author and country (Durga, 2010). The factors influencing consumers buying behaviour of bottled water in Ghana have not been fully understood. Although it is generally understood by consumers of bottle water that the product is better in some or all aspects than tap water, Ferrier (2001) and NRDC (2008) concluded in their study that, this is not always the case. Several studies have emphasized several factors which determine the choice for bottled water. Doria (2006) outlined dissatisfaction with tap water and health/risk concerns as the reasons why consumers choose to drink bottled water. Theoretically, Kotler et al. (2008) argue that consumers' purchases are strongly influenced by cultural, social, personal, and psychological factors. In her study about Suriname markets, Durga, (2010) asserted that demographic and psychological factors affect bottled water buying decision.

\subsection{Problem Statement}

In Ghana, demand for bottled water is high, reflecting the high temperatures in the country throughout the years. Notwithstanding the fact that there is limited statistics to back this assertion, consumption rate and sales volume have increased over the years looking at the number of bottled water companies now in Ghana. This no doubt reflects the global trend. There are twenty (20) companies registered by the Food and Drugs Board to produce 
bottled water. These companies in all account for about $95 \%$ of the bottled water available locally on the market (Sutton \& Kpentey, 2012). The local brands include among others, Voltic, Bon Aqua, Safina, Aqua Fill, Bell Aqua, Ice Cool, Special Ice, Still Pure and Smile Natural Mineral Water. The leading local bottled water producers are Voltic Ghana Limited, Coca Cola Bottling Company of Ghana Limited, Ice Cool Purified Water Limited and Evian. Brands like Vittel, Comtrex, Volvic and Evian are imported by Yes Mineral Limited (Sutton \& Kpentey, 2012). In short, both the global and local bottled water market are turning into a vital part of the beverage industry. This outstanding increment elicit several questions and is therefore one of the reasons for the research.

\subsection{Research Questions}

1.3.1 What is the relationship between demographic factors and consumer buying behaviour of bottled water?

1.3.2 What is the relationship between perception and consumer buying behaviour of bottled water?

\subsubsection{What is the relationship between belief and consumer buying behaviour of bottled water?}

1.3.4 What other factors determine the buying behaviour of consumers of bottled water in Ghana?

\section{Literature Review}

\subsection{Theoretical Review}

\subsubsection{Consumer Behaviour}

In marketing of goods and services, the concept of consumer behaviour is critical because, companies deal with customers who are different in nature.To help identify what is important to the consumer, understanding of consumer behaviour is key. This will help suggest the important influences on consumers' decision making, enabling marketers to provide goods and services that meet the needs of their target market.Loudon and Bita (1994) gave this definition for consumer behaviour as "the physical activity and decision process individuals engage in when evaluating, acquiring, using or disposing of goods and services" Consumer buying behaviour refers to the buying behaviour of final consumers - individuals and households who buy goods and services for personal consumption (Kotler, Armstrong, Wong, \& Saunders, 2008). The study of consumer behaviour focuses on how individuals make decisions to spend their available resources (time, money, effort) on consumption related items (Schiffman \& Kanuk, 2004, p. 5). Consumer behaviour then comprises concepts drawn from psychology, sociology, anthropology, history and economics.

\subsubsection{Consumer Decision Making Theories}

According to Shao (2006), the decision literature can be classified into three broad categories: 1) normative 2) behavioural, and 3) naturalistic. In this section the differences between the three different approaches to studying consumer decision behaviour are discussed.

\subsubsection{Normative Decision Theory}

Normative Decision Theory originated in the economic discipline. According to Shao (2006), earliest researchers saw decision-making as gambles and decision makers as "economic" men striving to maximize payoffs. The word 'normative' describes how people who make decisions should behave in order to gain maximum payoffs. Examples of this include Expected Utility Theory adapted by Neumann \& Morgenstern (1947) and Subjective Expected Utility Theory adapted by Savage (Shao, 2006).

One important addition to the Expected Utility Theory is the Subjective Expected Utility Theory propounded by Savage (Shao, 2006). The main difference between the two is that, the first uses objective probabilities, while the other uses subjective probabilities. By using subjective probabilities for objective probabilities, Subjective Expected Utility Theory states that the decision maker may not be sure about whether the various outcomes (payoffs) will actually occur if the option is chosen (Beach, 1997). Schoemaker (1982), on the other hand states that Normative Decision Theory is actually a bulk of theories and at their core is a rational decision maker. The implied decision process is a single-stage process of persistent and consistent calculations of the options' utilities. Schoemaker also stated that consumer decision-making process is a complex one in nature. Notwithstanding this, Beach (1997) states that the normative assumptions are imposing an order on the complexity of decision-making. As time goes on, there has been growing dissatisfaction with the normative approach to studying and understanding consumer decision-making because the observed decision behaviour often violates the underlying assumptions of Normative Decision Theory.

\subsubsection{Behavioural Decision Theory}

Behavioural Decision Theory emerged when decision researchers observed that decision makers seldom make 
explicit tradeoffs, let alone explicit use of probability and their preferences are constructed, not invariant (Bettman et al., 1998). The rational decision maker depicted by Normative Decision Theory was challenged by Simon (1955) who argued that decision makers have only bounded rationality and is seeking to satisfice. He also argued that Normative Decision Theory put high demand upon the choosing organism and those consumers do not necessarily search for all available alternatives, but choose the first feasible alternative that exceeds a given amount of payoffs. However, he also proposed classic satisfying strategy that was employed by decision makers in complex choice situations (Shao, 2006).

\subsubsection{Naturalistic Decision Theory}

Naturalistic Decision Theory emanated from the discipline of organizational behaviour. According to Shao (2006), many studies have developed various naturalistic decision models based on their views of how decisions are made by individuals in natural environments. For instance, a decision maker such as a fire ground commander will first recognize the fire situation, generate a few potential plans of actions, use cognitive imagination to assess the appropriateness of each plan to controlling the fire, and then act on the plan that he believes is the most appropriate (Orasanu \& Connolly, 2009).

\subsubsection{Personal Factors Influencing Consumers' Purchasing Decision}

There are some personal factors that influence the consumer to make purchase. In line with this study, the following personal factors have been discussed.

\subsubsection{Age and Stage in the Life Cycle}

Our taste in food, clothes, furniture, and recreation is often related to our age. Consumption is also shaped by the family life cycle, the number, age, and gender of people in the household at any point in time. In most countries, households are increasingly fragmented-the traditional family of four with a husband, wife, and two kids makes up a much smaller percentage of total households than it once did. In addition, psychological life-cycle stages may matter. Adults experience certain "passages" or "transformations" as they go through life. Yet, the behaviour people exhibit as they go through these passages, such as becoming a parent, is not necessarily fixed but changes with the times. Marketers should also consider critical life events or transitions - marriage, childbirth, illness, relocation, divorce, career change, widowhood - as giving rise to new needs. These should alert service providers-banks, lawyers, and marriage, employment, and bereavement counselors-to ways they can help (Kotler et al., 2001).

\subsubsection{Occupation and Economic Circumstances}

Occupation also influences consumption patterns. A blue-collar worker will buy work clothes, work shoes, and lunch boxes. A company president will buy dress suits, air travel, and country club memberships. Marketers try to identify the occupational groups that have above-average interest in their products and services and even tailor products for certain occupational groups: Computer software companies, for example, design different products for brand managers, engineers, lawyers, and physicians.

Product choice is greatly affected by economic circumstances: spendable income (level, stability, and time pattern), savings and assets (including the percentage that is liquid), debts, borrowing power, and attitudes toward spending and saving (Kotler et al., 2001).

\subsubsection{Personality and Buying Behaviour}

Each person's distinct personality influence his or her buying behavior. According to Kotler et al. (2001), personality refers to the unique psychological characteristic that lead to relative consistent and lasting response to one's own environment. Personality is usually described in terms of traits such as self-confident, dominance; sociability is autonomy, defensiveness, adaptability and aggressiveness. For example, coffee drinkers tend to be high on sociability. Thus, Nescafe ads show people coming together over a cup of coffee. Many marketers use a concept related to personality - a person's possessions contribute to and reflect their identities as stated by Schiffman and Kunk (2004).

\subsection{Empirical Literature}

Several studies over the past years investigated what factors have been influencing the buying behavior of consumers toward bottled water. However, their outcomes of these studies and opinions of researchers vary widely.

In 2006, Doria stated in his article "Bottled water versus Tap water: understanding Consumers' Preferences" that, many studies have shown clearly two main drivers for bottled water consumption. These drivers he mentioned concern consumers buying behavior in USA, Canada and France. They are: organoleptic (water 
characteristics that affect the senses of taste, odor and sight) and health and risk concerns (risk concerns may be seen as safety). In the same article, Doria (2006) argued that many consumers in these developed countries are neither satisfied nor dissatisfied with the quality of the tap water. Moreover, in communities that have serious problems with their tap water, bottled water consumption has often been high. These problems create new opportunities for bottled water producers and marketers, who package and present their products as 'pure', 'safe' and 'healthy'. He argued further that consumers are sensitive to the marketing of the business. Not only the advertisement, but also the packaging influences their buying behavior.

According to Doria (2006), as many consumers prefer products which seem to have higher health benefits then majority view bottled water to be reliable and in all healthier than other water. To this assessment, Rodwan (2009) partly sides with Doria (2006). Rodwan (2009) agreed in his report "Confronting Challenges" that the bottled water industry is just taking advantage of the growing health and well-being consciousness of consumers. On the other hand, he stated that consumers in developed countries perceive bottled water as a good alternative to other beverages, such as carbonated soft drinks and juices. Not only it is a way to achieve hydration for them, but bottled water is also healthy and thirst-quenching. Rodwan (2009) argues in contrast with Doria (2006) in the case of developing countries, where he thinks bottled water serves as an alternative since these countries often have unsafe water.

Contrary to both Doria (2006) and Rodwan (2009), Shandling (2008) did not come to a definite regional conclusion in her report "Global bottled water consumption on the rise". To her, the rise in bottled water consumption is because of an increased awareness of people of the need for and benefits of hydration for body and mind. She argued further by saying, bottled water is now becoming more accessible in growing economies such as Latin America and Eastern Europe. The results of this research will also show to what extent this theory is applicable to the Ghanaian market.

Phend (2009) alluded to the earlier studies findings of perceived purity, safety and taste as the main drivers for consumers to use bottled water. However, on the basis of a current survey conducted in England, she argued that health is not a driving factor at all in bottled water consumption. Rather, convenience and taste are the factors that drive the use of bottled water. Due to Phend's (2009) findings, the municipal water systems are improving and prices of bottled water are very high in comparison to tap water (Durga, 2010). In their study about "the role of branding in consumers choice of bottle water" in Nigeria, Ogbuji, Anyanwu \&Onah, (2010) discovered among other things that, of all the elements of branding, company-of-make and packaging play a greater role than brand name and brand mark, in terms of influencing consumer choice for bottled water.

In all, the reasons for bottled water consumption seem to vary; both by author and country. Health/risk concerns and taste seem to be the most frequently mentioned causes. The main deduction from the empirical literature is that, consumers generally value bottled water and are prepared to pay as high as they can to consume what they see to be a "safe", "healthy", "tasty" or "convenient" product. This study will unravel the Ghanaian perspective of the issue of factors influencing the buying behavior of bottle water.

\section{Method}

This research used the cross sectional survey design. This design was chosen because according to Donald and Pamela, (2003; p. 149), cross sectional studies are carried out once and represent a snapshot of one point in time. In this type of research study, either the entire population or a subset thereof is selected, and from these individuals, data are collected to help answer research questions of interest. In this research, the population of concern consists of all Ghanaians who live in the Accra metropolis and have at least a foundation education and are fifteen (15) years or older. The sampling frame in this case is the same as the population of concern. The sample frame is a set of items from which the sample is drawn. Since it is impossible to list all the people with above mentioned characteristics, the sample frame is the same as the population of concern. A sample size of two hundred and forty (240) bottle water consumers were selected using quota sampling technique, a form of nonprobability sampling. In quota sampling the population is first segmented into mutually exclusive sub-groups. The Metropolis was grouped into four (4) strata: Legon, 37 military Hospital Area, Circle Area and Makola. Judgmental sampling technique was then used to select sixty (60) respondents from all the four (4) strata, through a self-completion method. The four (4) areas were chosen because they are located in the center of the metropolis where people from most part of the country leave. This type of sampling is considered as the most appropriate one for this research because of two main reasons. Firstly, it enables the researcher to list relevant control characteristics and secondly it determines the distribution of these characteristics in the targeted population. Demographic data, such as age and sex, can more easily be explored by quota sampling. A selfadministered survey was used to collect the data. This enabled the respondents to answer questions directly on a 
questionnaire without an interviewer's interaction (McGraw-Hill, 2004).

Items measuring all the constructs were borrowed from some previous studies (Ogbuji, Anyanwu, \& Onah, 2010; Doria, 2006; Rodwan, 2009; Phend, 2009). Variables such as "bottled drinking bottled water is refreshing", "bottled drinking water suits my lifestyle", "bottled drinking water is relatively cheap in Ghana" were used to measure perceptions of bottled drinking water. Similarly, items such as "bottled drinking water has higher quality standards than sachet water", "bottled drinking water is safer than sachet water in Ghana", "bottled drinking water is healthier than carbonated drinks (soft drinks)" and items such as "bottled drinking is convenient and easy to consume, I purchase bottled drinking water frequently" were all measured. The validity of these items have been confirmed by some previous studies (Ogbuji, Anyanwu, \& Onah, 2010; Doria, 2006; Rodwan, 2009; Phend, 2009). To further provide a proof for the validity of the constructs, the Cronbach's alphas for the constructs were ascertained and they were all high; perception (.70), purchasing behaviour (.73) and beliefs (.67) The questions were measured on a four-point likert scale; (Strongly agree $=4$, Agree $=3$, Disagree $=2$, Strongly disagree $=1$ ). Frequencies and means were used to statistically summarize some main data of respondents for the researchers to get an overview and provided guidance for conducting further analysis. Again, Z-test, ANOVA and correlations amongst dependent (buying behaviour) and independent variables (demographic and Psychological factors) was carried out to identify the possible relationships.

\section{Results}

\subsection{Demographic Factors}

The analysis first looked at the demographic factors. The frequency table of the respondents' profile (table 1) shows that, in terms of gender, female (61.2\%) of the respondents drink bottled water compared to male (38.8\%). This result no wonder re-emphasizes the ratio of female to male in Ghana. This only shows the number of females or males willing to respond or to be sampled but does not mean from the percentages that females buy bottled water more frequently. In terms of age, the majority (43.3\%) of the respondents are between 15-25 years, followed by (34.6\%) between 26-34 years, (14.6\%) who are between 35-44 years and also (7.5\%) representing those who are 45 and above. It can be said that, teenagers and the middle age group are the dominant buyers of bottled water who are willing to be sampled. This is further explained by the result of education. In terms of education, $(50.8 \%)$ of the respondents who drink bottled water have undergraduate degrees, followed by Secondary/SHS (28.8\%), Masters level and above (14.6\%) and Primary/JHS (5.8\%). In Ghana, the majority of students in the Tertiary and SHS mostly fall within $15-25$ years and $26-34$ years. The income distribution shows that, respondents with lowest income 100-500 (38.3\%), followed by 600-1000 (27.9\%), 1100-1500 (19.6\%), $1600-2000(7.5 \%)$ and 2100 and above $(6.7 \%)$. As the researchers wait to see the results of the inferential analysis, it can be concluded that, demographic factors relates to bottled water buying behaviour.

Table 1. Demographic characteristics

\begin{tabular}{|c|c|c|c|c|}
\hline & Demographic factor & No. of respondents & Percetange (\%) & Cumulative Percentage (\%) \\
\hline \multirow[t]{3}{*}{1} & Gender & & & \\
\hline & Male & 93 & 38.8 & 38.8 \\
\hline & Female & 147 & 61.2 & 100 \\
\hline \multirow[t]{5}{*}{2} & Age & & & \\
\hline & 15 -25years & 104 & 43.3 & 43.3 \\
\hline & 26-34years & 83 & 34.6 & 77.9 \\
\hline & $35-44$ years & 35 & 14.6 & 92.5 \\
\hline & 45 and above & 18 & 7.5 & 100.0 \\
\hline \multirow[t]{5}{*}{3} & Education & & & \\
\hline & Primary/ JSH & 14 & 5.8 & 5.8 \\
\hline & Secondary/ SHS & 69 & 28.8 & 34.6 \\
\hline & Tertiary & 122 & 50.8 & 85.4 \\
\hline & Masters and above & 35 & 14.6 & 100.0 \\
\hline \multirow[t]{6}{*}{4} & Income (in GHS) & & & \\
\hline & $100-500$ & 92 & 38.8 & 38.3 \\
\hline & $600-1000$ & 67 & 27.9 & 66.2 \\
\hline & $1100-1500$ & 47 & 19.6 & 85.8 \\
\hline & $1600-2000$ & 18 & 7.5 & 93.3 \\
\hline & 2100 and above & 16 & 6.7 & 100.0 \\
\hline \multirow[t]{4}{*}{5} & Bottled water usage & & & \\
\hline & Once a week or more & 137 & 57.1 & 57.1 \\
\hline & Less than once a week & 54 & 22.5 & 79.6 \\
\hline & Less than once a month & 49 & 20.4 & 100.0 \\
\hline
\end{tabular}




\begin{tabular}{llll}
\hline 6 & & & \\
Main purchase location & 67 & 27.9 & 27.9 \\
At supermarkets & 69 & 28.8 & 56.7 \\
At bars/restaurants & 79 & 32.9 & 89.6 \\
At the road side/stations & 25 & 10.4 & 2.9 \\
Other & & 2.9 & 47.1 \\
Main reason to use bottled water & 7 & 44.2 & 62.5 \\
Tastes better than other drinks & 106 & 15.4 & 100.0 \\
Healthier/safer than other drinks & 37 & 37.5 & \\
It is thirst-quenching & 90 & & \\
It is convenient and easy to consume & & & \\
\hline
\end{tabular}

\subsection{Relationship between Personal Factors and Purchasing Decision}

This section analyses the results of the research questions and other notable findings. Firstly, the study presents the findings of the relationship between personal characteristics and purchasing decision and the second part presents the findings on the relationship between the psychological factors and purchasing decision.

In other to assess the relationship between gender and bottled water buying behaviour, an independent t-test was performed at $95 \%$ significant level to determine whether or not there is a significant difference between the two gender categories (Male and Female) regarding the frequency of bottled water usage or buying. The outcome is shown in table A1 in (Appendix A). From the outcome, it is clear that there is no significant difference between the two gender categories concerning the frequency of bottled water purchase. This conclusion is proper because, a probability value $(\mathrm{P}=0.633)$ is greater than the critical probability of $(0.05)$. The implication is that, there is no gender disparity between male and female when it comes to frequency of purchase of bottled water. Therefore, bottled water is assumed to be no gender-related product. Both male and female are (frequent) consumers of bottled water. The results also clarify the point that notwithstanding the fact that $(61.2 \%)$ of respondent are female and (38.8\%) are male, in terms of frequency of bottled water usage, there is no significant difference between them. This finding is in line with Durga's, (2010) findings. He concluded that there is no relationship between gender and bottled water buying behaviour.

The study also examined the relationship between age categories of respondents and frequency of purchase of bottled water. Analysis of variance (ANOVA) was performed to determine whether or not there is a significant difference among the means of the four age categories in terms of their buying behaviour or frequency of purchase. The output presented in table A2 of Appendix A shows that, there is a significant difference among the four age groups in terms of their buying behaviour of bottled water $(\mathrm{F}=10.449, \mathrm{P}=0.00)$. This means that, there is a significant difference among the age categories when compared to the alpha value of 0.05 . To find out which of the age groups show the difference, a multiple comparison test was further performed using Turkey's test and the outcome presented in the table A2 of Appendix A. From the outcome, it can be noticed that, respondents between the ages of 15-25 years is significantly different from the respondents above the ages of 25years in terms of frequency of buying bottled water. However, the respondents above 25 years show no significant difference among the age groups. This implies that, respondent above 25 years buy bottled water more frequently (mean $\geq$ 3.48) than respondent between 15-25 years of age with the mean (3.08). But the difference in terms of frequency among the age groups above 25 years is not so significant compared to difference in frequency of purchase between the ages 15-25 years and 25 years and above.

In other to examine the relationship between the level of education of respondents and frequency of purchase of bottled water, ANOVA was performed to determine whether or not there is a significant difference among the means of the various levels of education of respondents in terms of their buying behaviour or frequency of purchase. The output is presented in Table A3 of Appendix A. The output shows that there is a significant difference among the four levels of education in terms of their buying behaviour of bottled water $(\mathrm{F}=18.559$, $\mathrm{P}=0.00$ ). This means that, there is a significant difference among the levels of education of respondents when compared to the alpha value of 0.05 . To find out which of these levels of education show the difference, a multiple comparison test was further performed using Turkey's test and the outcome presented in table A4 (Appendix A). From the outcome, taking the mean differences into consideration shows a significant difference among all the educational levels in terms of frequency of buying bottled water. The implication is that, the higher the level of education, the higher the frequency of bottled water purchase and use. This finding is in sharp contrast with Durga (2010) results, whose empirical findings in the Surinamese market concluded that there is no relationship between education and bottled water buying behaviour.

The ANOVA between income categories and 'bottled water buying behaviour' was performed to see the relationship among income levels and the frequency of bottled water buying. The table A5 shows $(\mathrm{F}=11.269, \mathrm{P}=$ 
0.00 ) that there is a significant difference among the categories of income levels in terms of frequency of purchase of bottled water when compared to the critical probability value of $(0.05)$. Since significance is shown, a multi comparison test is conducted for the variable income levels. This test identifies which income levels show significance on buying behaviour. Table A6 of Appendix A shows the results from the SPSS. It can be seen that respondents with income levels between (GHS100-500) is significantly different from respondents with income above GHS500 in terms of frequency of bottled water purchasing. However, the respondents with income above GHS500 show no significant difference among the income groups. The implication is that, respondents with income above GHS500 buy bottled water more frequently (mean $\geq 3.43$ ) than respondent with income between GHS100-500 with the mean (3.0). In other words, respondents with income levels between GHS 100-500 buy bottled water frequently but not as frequent as those with income levels above GHS500. This finding is in an agreement with Durga's (2010), whose empirical work concludes that there is a relationship between income levels and bottled water buying behaviour in the Suriname market.

\subsection{Relationship between Psychological Factors and Purchasing Decision}

The correlation range and size above is the basis for making decision about the psychological factors: beliefs and perceptions below.

Table 2. Correlation size on the basis of the range

\begin{tabular}{ll}
\hline Correlation range & Size of correlation \\
\hline $0.01-0.29$ & Small \\
$0.30-0.49$ & Medium \\
$0.50-1.0$ & Large \\
\hline
\end{tabular}

Source: Pallant (2007).

In other to assess the relationship between beliefs and bottled water buying behaviour in terms of frequency of use, Pearson Correlation is performed and the result is shown in the appendix (see Table A7). The r-value (0.196) of the variable beliefs shows that, there is a small positive relationship between beliefs and buying behaviour. This implies that, when respondents' beliefs for bottled water increase the rate and frequency of bottled water consumption also increases. This can be explained by the overall positive beliefs of bottled water. This can be seen from the fact that most consumers believe that bottled water is healthier, safer and it is a product of higher quality standards compared to sachet water. Hence, belief variable of bottled water has small positive influence on the frequency of buying bottled water.

In other to assess the relationship between perception and bottled water buying behaviour in terms of frequency of use, Pearson Correlation is performed and the result is shown in the appendix (see Table A7). The r-value of 0.239 between the variable perception and buying behaviour indicates that there is a small positive relationship between perception and buying behaviour. This can also be found again in the fact that respondents react positively on all statements regarding their perception of bottled water. Hence, besides all positive beliefs they have of bottled water, a dominating part of $50.8 \%$ perceives bottled water as 'convenient and easy to consume'. Majority also (49.4\%) perceive the taste of bottled water to be better than the taste of tap water, while $65 \%$ agree also that drinking bottled water is more refreshing. The implication is that, when respondents' perception for bottled water increase the rate and frequency of bottled water consumption also increases.

\section{Discussion of Findings}

In testing the hypothesis, the demographic factors were first tested. The results show that, there is a relationship between age categories, income groups, educational levels and bottled water buying behaviour in the Ghanaian market. With respect to age and income, respondents above 25 years and the income levels above GHS500 buy bottled water more frequently than the ages between (15-25 years) and income levels between (GHS100-500). Significant differences among all the educational levels imply that, as consumers go higher on the educational ladder, the more they consume bottled water frequently. However, gender did not show any relationship with buying behaviour. In conclusion, there is a relationship between demographic factors and bottled water buying behaviour.

Considering the psychological factors, perception and beliefs show a relationship with the frequency of bottled water usage. The small correlation means then that, high perception and beliefs of the product also lead to a more frequent buying behaviour. It is assumed that the more positive perception someone has about a product, the bigger the motivation to use the product. Consumers describe bottled water as safe, healthy, reliable, convenient, 
good and available, refreshing, socially accepted and a good alternative to other drinks. In comparison to sachet water, the respondents perceive bottled water as healthier, safer and of higher quality. Considering the fact that there is no absolute proof yet that bottled water is better than sachet water in any aspect(s), the beliefs and perception variables of bottled water may be the result of heavy - and even at times misleading - advertising. Therefore, it is attractive for consumers to use. As consumers are more sensitive to this information, the bottled water business keeps growing. To conclude, there is a relationship between psychological factors and bottled water buying behaviour.

The study identified four factors which influence the respondents mostly when purchasing bottled water. These are: quality, brand price, availability and package. Hence, the theory of Doria (2006) is valid for the Ghanaian market: package does influence consumers' buying behaviour of bottled water.

This study recommends that marketers of bottled water should focus their communication more on health/safety and the convenience benefits of the product to the target audience. Also, in as much as they distribute their product to other points of sales like supermarket and others, more attention should be paid to the shops at the road side/bus stations as it is the main purchase location of the respondents in the Ghanaian market.

The researchers recommend that further research should cover other influencing factors of bottled water purchase such as lifestyle and culture. Since this research is focused on a relatively small part of the factors, a research focusing on an integrated model is recommended. This may prove more useful in consumer buying behavior theory and can therefore be a better guide for bottlers/producers/marketers of bottled water.

\section{Acknowledgments}

The authors want to thank Henry Boateng for his intial comments and suggestions.

\section{References}

Assael, H. (1994). Consumer Behavior and Market Action. Boston, Massachusetts: Kent Publishing Company.

Bachman, G. R., John, D. R., \& Rao, A. R. (1993). Children's Susceptibility to Peer Group Purchase Influence: An exploratory Investigation. Advances in Consumer Research, 20(3), 463-468.

Beach, L. R. (1997). The psychology of decision making: People in organizations. Thousand Oaks: Sage Publications.

Beach, L. R. (1997). The psychology of decision making: People in organizations. Thousand Oaks: Sage Publications.

Bettman, J. R., Luce, M. F., \& Payne, J. W. (1998). Constructive consumer choice processes. Journal of Consumer Research, 25(3), 187-217. http://dx.doi.org/10.1086/209535

Biemer, P. P., \& Lyberg, L. E. (2003). Introduction to Survey Quality. Hoboken, NJ: John Wiley \& Sons; Oaks: Sage Publications. http://dx.doi.org/10.1002/0471458740

Cadogan, J. W., \& Foster, B. D. (2000). Relationship Selling and Customer Loyalty: An Empirical Investigation. Marketing Intelligence and Planning, 18(4), 185-199. http://dx.doi.org/10.1108/02634500010333316

Clow, M. (2010). Integrated Marketing Communications. Pearson Education, Inc. publishing as Prentice Hall.

Cooper, D. R., \& Schindler, P. S. (2003). Business Research Methods. New York: McGraw Hill.

Creswell, J. W. (1994). Research Design: Qualitative and Quantitative Approaches. Sage Publications: Thousand Oaks, CA.

De Ruyter, K., Wetzels, M., \& Van Birgelen, M. (1999). How Do Customers React to Critical Service Encounters: A Cross-sectional Perspective. Total Quality Management, 10(8), 1131-1135. http://dx.doi.org/10.1080/0954412997118

Dissertation, Griffith Business School, Australia.

Doria, M. F. (2006). Bottled water versus Tap water: understanding consumers' preferences. Journal of Water and Health, 271-276.

Drake, I. (2010). Asia boosts global bottled water market. Retrieved February 15, 2010, from http:/www.ausfoodnews.com.au/2010/01/15/asia-boosts-global-bottled-watermarket.htm.1

Duff, M. (2007). Niche Marketing of cosmetics, DSN Retailing Today, 38, 29-35.

Durga, M. (2014). Consumer' buying behavior of bottled water in Surinam, August 25, pp.57.

Engel, J. F., Blackwell, R. D., \&Minard, P. W. (1990). Consumer Behavior London. Dryden Press. Retrieved 
from http://assets.panda.org/downloads/bottledwater.pdf

Ferre. (2009). Bottled water industry under pressure but drinks growth to be robust. Retrieved from http://www.ausfoodnews.com.au/2009/03/19/bottled-water-industry-under-pressure-but-drinks-growth-tobe-robust.html

Ferrier, C. (2001). Bottled water: understanding a social phenomenon. http://dx.doi.org/10.1579/0044-744730.2 .118

Finlayson, D. (2005). Market development of bottled waters. In D. Senior \& N. Dege (Eds.), Technology of bottled water (2nd ed., p. 6). UK: Blackwell Publishing.

Frings, G. S. (2005). Fashion: From Concept to Consumer (8th ed.). New Jersey: Pearson/ Prentice Hall.

Hawkins, D. I., Best, R. J., \& Coney, K. A. (2004). Consumer Behavior: Building Marketing Strategy (9th ed.). New York, McGraw Hill/ Irwin.

Hawkins, D., Best, R., \& Coney, K. (2000). Consumer Behavior Building Marketing Strategy.

Hoyer, W., \& Maclnnis, D. (2007). Consumer Behavior. Boston: Houghton Mifflin Company.

Johnson, B., \& Christensen, L. (2008). Educational research: Quantitative, qualitative, and mixed approaches (p. 34). Thousand Oaks, CA: Sage Publications.

Keller, K. L. (2003). Strategic Brand Management: Building, Measuring and Managing Brand Equity. New Jersey: Prentice Hall.

Kohli, C., \& Thakor, M. (1997). Branding Consumer Goods: Insights from Theory and Practice. Journal of Consumer Marketing, 14(3), 206-219. http://dx.doi.org/10.1108/07363769710166792

Kotler, P., Armstrong, G., Wong, V., \& Saunders, J. (2001). Principles of Marketing (Third European). Essex: Pearson Education Limited.

Kotler, P., Armstrong, G., Wong, V., \& Saunders, J. (2005). Principles of Marketing (5th ed.).

Kotler, P., Armstrong, G., Wong, V., \& Saunders, J. (2008). Principles of Marketing (5th ed.). England: Pearson Education Limited.

Lin, M. Y., \& Chang, L. H. (2003). Determinant of Habitual Behavior for National and Leading Brand in China. Journal of Product and Brand Management, 12(2), 94-107. http://dx.doi.org/10.1108/10610420310469788

Loudon, D., \& Della Bitta, A. (1994). Consumer Behavior Application (4th ed.). New York: McGraw Hill.

Lovelock, C. H. (2010). Services Marketing (4th ed.). New Jersey: Prentice Hall. England: Pearson Education Limited.

Mackenzie, I. (2004). English for Business Studies-A course for Business Studies and Economics students. Cambridge, United Kingdom; Cambridge University Press.

Manisah Durga, (2010). Consumer Buying Behavior in Suriname, A Study on the Demographic and Psychological factors and Bottled Water Buying Behavior. Retrieved 15, 2012 from http://www.fhrinstitute.org/plueginfile.php/33/modpage/content/1/resources/MBA\%20en\%20MPA\%20grad uates\%20and20iectures/MBA20info/MBA-5-Thesis-subjects.pd.

McGraw-Hill. (2004). Glencoe Marketing Essentials. Retrieved from www.glencoe.com

Mowen, J. C., \& Minor, M. (1998). Consumer Behavior (5th ed.). New Jersey: Prentice Hall.

National Resources Defense Council. (2008). Bottled water. Retrieved from http://www.nrdc.org/Water/Drinking/qbw.asp

Omar, O. E. (1999). Retail Marketing. Harlow: Pearson Education.

Orasanu, J., \& Connolly, T. (Eds.). (1993). The reinvention of decision making. Norwood: Ablex Publishing.

Palmer, D. (2009). Bottled water industry gets boost from developing economies. Retrieved from http://www.ausfoodnews.com.au/2009/09/03/global-bottled-water-industry-gets-boost-from-developingeconomies.html

Peter, J. P., \& Olson, J. C. (2005). Consumer behavior \& Marketing Strategy. New York: McGraw Hill Companies, Inc.

Russell, R. S., \& Taylor, B. W. (2006). Operation Management: Quality and Competitiveness in a Global Environment (5th ed). New Jersey: John Wiley \& Sons, Inc. 
Savage, L. J. (1954). Foundations of statistics. New York: Wiley.

Schiffman, L. G., \& Lazar Kanuk, L. (2004). Consumer Behavior (8th ed.). Englewood Cliffs, NJ: Prentice-Hall.

Schoemaker, P. J. H. (1982). The expected utility model: It's variants, purposes, evidence and limitations. Journal of Economic Literature, 20(2), 529-563.

Shao, W. (2006). Consumer decision making: An empirical exploration of multi-phrased decision process. $\mathrm{PhD}$

Simon, H. A. (1955). A behavioral model of rational choice. The Quarterly Journal of Economics, 69(1), 99-118. http://dx.doi.org/10.2307/1884852

Simons, A., Irwin Donald, B., \& Drinnien Beverly, A. (1987). Online article of Maslow's Hierarchy Needs of Consumer Behavior. West Publishing Company: New York.

Sproles, G. B., \& Kendall, E. L. (1986). A methodology for profiling consumer decision-Making design. The Journal of Consumer Affairs, 20, 267-279. http://dx.doi.org/10.1111/j.1745-6606.1986.tb00382.x

Stoler, J., Weeks, J. R., \& Fink, G. (2012). Sachet drinking water in Ghana's Accra-Tema metropolitan area: past, present, and future. Journal of Water, Sanitation and Hygiene for Development. http://dx.doi.org/10.2166/washdev.2012.104

Sutton, J., \& Kpentey, B. (2012). An Enterprise Map of Ghana (p. 66). Retrieved from http://personal./se.ac.uk/sutton/Ghana find check.pdf

Sutton, J., \& Kpentey, B. (2012). An enterprise map of Ghana. International Growth Centre.

Voltic Ghana Limited (a Subsidiary of SABMiller plc.) Retrieved 15 October, 2012, from www.sabmiller.com.

Wiki Answers. (2010). What is exploratory research? Retrieved from http://wiki.answers.com/ Q/ what is exploratory research

Wikipedia. (2010). Bottled water. Retrieved from http://en.Wikipedia.org/wi Bottled water Sanitation and Hygiene for Development | 02.4 | 2012 Journal of Water, Sanitation and Hygiene for Development | $02.4 \mid$ 2012 www.google.com/AccraMetropolitan Assembly

Wong, F. Y., \&Yahyah, S. (2008). Influence of Brand Loyalty on Consumer Sportswear, Int. Journal of Economics and Management, 2, 221-236.

Yoon, S. J., \& Kim, J. H. (2000). An Empirical Validation of a Loyalty Model based on Expectation and $\begin{array}{lllll}\text { Disconfirmation. Journal of } & \text { Consumer }\end{array}$ http://dx.doi.org/10.1108/07363760010317196

\section{Appendix A}

Table A1. T-test of gender and bottled water buying behavior

\begin{tabular}{|c|c|c|c|c|c|c|c|c|c|c|}
\hline & & \multicolumn{2}{|c|}{$\begin{array}{l}\text { Levene's Test } \\
\text { for Equality of } \\
\text { Variances }\end{array}$} & \multicolumn{7}{|c|}{ t-test for Equality of Means } \\
\hline & & \multirow[t]{2}{*}{$\mathrm{F}$} & \multirow[t]{2}{*}{ Sig. } & \multirow[t]{2}{*}{$\mathrm{t}$} & \multirow[t]{2}{*}{$\mathrm{df}$} & \multirow[t]{2}{*}{$\begin{array}{l}\text { Sig. (2- } \\
\text { tailed) }\end{array}$} & \multirow[t]{2}{*}{$\begin{array}{l}\text { Mean } \\
\text { Difference }\end{array}$} & \multirow[t]{2}{*}{$\begin{array}{l}\text { Std. Error } \\
\text { Difference }\end{array}$} & \multicolumn{2}{|c|}{$\begin{array}{l}\text { 95\% Confidence } \\
\text { Interval of the } \\
\text { Difference }\end{array}$} \\
\hline & & & & & & & & & Lower & Uppe \\
\hline \multirow[t]{2}{*}{$\begin{array}{l}\text { Buying } \\
\text { behavior }\end{array}$} & $\begin{array}{l}\text { Equal variances } \\
\text { assumed }\end{array}$ & 1.752 & .187 & .478 & 238 & .633 & .051 & .106 & -.159 & .261 \\
\hline & $\begin{array}{l}\text { Equal variances not } \\
\text { assumed }\end{array}$ & & & .486 & 206.067 & .627 & .051 & .105 & -.156 & .257 \\
\hline
\end{tabular}

Table A2. ANOVA of age and bottled water buying behavior

\begin{tabular}{llllll}
\hline & Sum of Squares & df & Mean Square & F & Sig. \\
\hline Between Groups & 18.026 & 3 & 6.009 & 10.449 & .000 \\
Within Groups & 135.708 & 236 & .575 & & \\
Total & 153.733 & 239 & & & \\
\hline
\end{tabular}


Table A3. Multi comparison test and ANOVA of variable age

\begin{tabular}{|c|c|c|c|c|c|c|}
\hline \multirow{2}{*}{$\begin{array}{l}\text { (I) Ages of bottled } \\
\text { water consumers in } \\
\text { the Accra Metropolis }\end{array}$} & \multirow{2}{*}{$\begin{array}{l}(\mathrm{J}) \text { Ages of bottled } \\
\text { water consumers in } \\
\text { the Accra } \\
\text { Metropolis }\end{array}$} & \multirow{2}{*}{$\begin{array}{l}\text { Mean } \\
\text { Difference (I-J) }\end{array}$} & \multirow[t]{2}{*}{ Std. Error } & \multirow[t]{2}{*}{ Sig. } & \multicolumn{2}{|c|}{$95 \%$ Confidence Interval } \\
\hline & & & & & Lower Bound & Upper Bound \\
\hline \multirow[t]{3}{*}{ 15-25years } & 26-34years & $-.405^{*}$ & .112 & .002 & -.69 & -.12 \\
\hline & $35-44$ years & $-.723^{*}$ & .148 & .000 & -1.11 & -.34 \\
\hline & 45 and above & $-.590^{*}$ & .194 & .014 & -1.09 & -.09 \\
\hline \multirow[t]{3}{*}{ 26-34years } & 15-25years & $.405^{*}$ & .112 & .002 & .12 & .69 \\
\hline & 35-44years & -.318 & .153 & .162 & -.71 & .08 \\
\hline & 45 and above & -.185 & .197 & .785 & -.69 & .33 \\
\hline \multirow[t]{3}{*}{ 35-44years } & 15-25years & $.723^{*}$ & .148 & .000 & .34 & 1.11 \\
\hline & 26-34years & .318 & .153 & .162 & -.08 & .71 \\
\hline & 45 and above & .133 & .220 & .930 & -.44 & .70 \\
\hline \multirow[t]{3}{*}{45 and above } & $15-25$ years & $.590^{*}$ & .194 & .014 & .09 & 1.09 \\
\hline & 26-34years & .185 & .197 & .785 & -.33 & .69 \\
\hline & 35-44years & -.133 & .220 & .930 & -.70 & .44 \\
\hline
\end{tabular}

*. The mean difference is significant at the 0.05 level.

Table A4. ANOVA of education and bottled water buying behavior

\begin{tabular}{llllll}
\hline & Sum of Squares & Df & $\begin{array}{l}\text { Mean } \\
\text { Square }\end{array}$ & F & Sig. \\
\hline Between Groups & 29.341 & 3 & 9.780 & 18.556 & .000 \\
Within Groups & 124.392 & 236 & .527 & & \\
Total & 153.733 & 239 & & & \\
\hline
\end{tabular}

Table A5. ANOVA of income and bottled water buying behavior

\begin{tabular}{llllll}
\hline & Sum of Squares & df & Mean Square & F & Sig. \\
\hline Between Groups & 24.742 & 4 & 6.185 & 11.269 & .000 \\
Within Groups & 128.992 & 235 & .549 & & \\
Total & 153.733 & 239 & & & \\
\hline
\end{tabular}

Table A6. Multi comparison test and ANOVA of variable education

\begin{tabular}{|c|c|c|c|c|c|c|}
\hline \multirow{3}{*}{$\begin{array}{l}\text { (I) Monthly income of } \\
\text { bottled water } \\
\text { consumers in the } \\
\text { Accra Metropolis }\end{array}$} & \multirow{3}{*}{$\begin{array}{l}\text { (J) Monthly income of } \\
\text { bottled water } \\
\text { consumers in the } \\
\text { Accra Metropolis }\end{array}$} & \multirow[t]{3}{*}{$\begin{array}{l}\text { Mean Difference (I- } \\
\text { J) }\end{array}$} & \multirow[t]{3}{*}{ Std. Error } & \multirow[t]{3}{*}{ Sig. } & \multicolumn{2}{|c|}{$\begin{array}{l}95 \% \text { Confidence } \\
\text { Interval }\end{array}$} \\
\hline & & & & & Lower & Upper \\
\hline & & & & & Bound & Bound \\
\hline \multirow[t]{4}{*}{$100-500$} & $600-1000$ & $-.433^{*}$ & .119 & .003 & -.76 & -.11 \\
\hline & $1100-1500$ & $-.617^{*}$ & .133 & .000 & -.98 & -.25 \\
\hline & $1600-2000$ & $-.833^{*}$ & .191 & .000 & -1.36 & -.31 \\
\hline & 2100 and above & $-.938^{*}$ & .201 & .000 & -1.49 & -.39 \\
\hline \multirow[t]{4}{*}{$600-1000$} & $100-500$ & $.433^{*}$ & .119 & .003 & .11 & .76 \\
\hline & $1100-1500$ & -.184 & .141 & 687 & -.57 & .20 \\
\hline & $1600-2000$ & -.400 & .197 & .252 & -.94 & .14 \\
\hline & 2100 and above & -.505 & .206 & .106 & -1.07 & .06 \\
\hline \multirow[t]{4}{*}{$1100-1500$} & $100-500$ & $.617^{*}$ & .133 & .000 & .25 & .98 \\
\hline & $600-1000$ & .184 & .141 & .687 & -.20 & .57 \\
\hline & $1600-2000$ & -.216 & .205 & .830 & -.78 & .35 \\
\hline & 2100 and above & -.320 & .214 & .567 & -.91 & .27 \\
\hline \multirow[t]{4}{*}{$1600-2000$} & $100-500$ & $.833^{*}$ & .191 & .000 & .31 & 1.36 \\
\hline & $600-1000$ & .400 & .197 & .252 & -.14 & .94 \\
\hline & $1100-1500$ & .216 & .205 & .830 & -.35 & .78 \\
\hline & 2100 and above & -.104 & .255 & .994 & -.80 & .60 \\
\hline \multirow[t]{4}{*}{2100 and above } & $100-500$ & $.938^{*}$ & .201 & .000 & .39 & 1.49 \\
\hline & $600-1000$ & .505 & .206 & .106 & -.06 & 1.07 \\
\hline & $1100-1500$ & .320 & .214 & .567 & -.27 & .91 \\
\hline & $1600-2000$ & .104 & .255 & .994 & -.60 & .80 \\
\hline
\end{tabular}

*. The mean difference is significant at the 0.05 level. 
Table A7. Correlations between beliefs/perception and bottled water buying behavior

\begin{tabular}{lllll}
\hline & & believe & Perception & Buying Behavior \\
\hline Believe & Pearson Correlation & 1 & $.285^{* *}$ & $.196^{* *}$ \\
& Sig. (2-tailed) & & .000 & .002 \\
& $\mathrm{~N}$ & 240 & 240 & 240 \\
\hline Perception & Pearson Correlation & $.285^{* *}$ & 1 & $.239^{* *}$ \\
& Sig. (2-tailed) & .000 & & .000 \\
& $\mathrm{~N}$ & 240 & 240 & 240 \\
\hline Buying Behaior & Pearson Correlation & $.196^{* *}$ & $.239^{* *}$ & 1 \\
& Sig. (2-tailed) & .002 & .000 & \\
& $\mathrm{~N}$ & 240 & 240 & 240 \\
\hline
\end{tabular}

**Correlation is significant at the 0.01 level (2-tailed).

\section{Copyrights}

Copyright for this article is retained by the author(s), with first publication rights granted to the journal.

This is an open-access article distributed under the terms and conditions of the Creative Commons Attribution license (http://creativecommons.org/licenses/by/3.0/). 